important pathological processes may be present. This study sheds little light on whether these processes are primarily organic or associated with psychological or family dynamics. Nevertheless, our findings suggest that when a parent complains of food intolerance in a child, particularly when it is long standing and associated with multiple food avoidance, the complaint needs to be taken seriously by general practitioners and hospital doctors.

We thank all the parents and children who have taken part in the national study of health and growth and acknowledge the work done by nurses, clerks, administrators, teachers, and doctors in each study area. We thank all our colleagues on the study team who have collected, coded, processed, and typed the information and Professor W W Holland for his continued support and encouragement. The study is funded through the Department of Health and Social Security and the Scottish Home and Health Department.

\section{References}

1 Rona RJ, Chinn S. Parents' perceptions of food intolerance in primary school children. Br Med f 1987;294:863-6.
2 Van Dellen RG, Reed CE. Allergy to drugs, food and food additives. In: Goetzl EJ, Kay AB, eds. Current perspectives in allergy. Edinburgh: Churchill Livingstone, 1982:130-41.

3 Pearson DJ. Food allergy, hypersensitivity and intolerance. I $R$ Coll Physicians Lond 1985;19: 154-62.

4 Lessof MH. Food intolerance and allergy. Q J Med 1983;206:111-9.

5 Tanner JM. Physical development. Br Med Bull 1986;42:131-8.

6 Altman DG, Cook J. A nutritional surveillance study. Proceedings of the Royal Sociery of Medicine 1973;66:646-7.

7 Tanner JM, Whitehouse RH, Takaishi M. Standards from birth to maturity for height, weight, height velocity and weight velocity: British children 1965. Arch Dis Child 1966;41:454-71.

8 Minford AMB, Macdonald A, Littlewood JM. Food intolerance and food allergy in children: a review of 68 cases. Arch Dis Child 1982:57:742-7.

9 Bock SA. A critical evaluation of clinical trials in adverse reactions to foods in children. $\mathcal{f}$ Allergy Clin Immunol 1986;78:165-73.

10 Warner JO, Hathaway MJ. Allergic form of Meadow's syndrome (Munchausen by proxy). Arch Dis Child 1984;59:151-6.

11 Pearson DJ, Rix KJ. Food allergy: How much in the mind? A clinical and psychiatric study of suspected food hypersensitivity. Lancet 1983;i:1259-61.

12 Bender AE, Mathews DR. Adverse reactions to foods. British fournal of Clinical Nutrition $1981 ; 46: 403-7$

13 Groll A, Candy DCA, Preece MA, Tanner JM. Short stature as the primary manifestation of coeliac disease. Lancet 1980;i:1097-9.

14 Buisseret PD. Common manifestations of cows' milk allergy in children. Lancet 1978;i:304-5.

15 Rossiter MA. Food intolerance-a general paediatrician's view. $\mathcal{J} R$ Soc Med 1985;5(suppl): $17-20$.

16 Stern M, Walker WA. Food allergy and intolerance. Pediatr Clin North Am 1985;32:471-92.

\title{
Abnormal flow properties of white blood cells in patients with severe ischaemia of the leg
}

\author{
G B NASH， P R S THOMAS, J A DORMANDY
}

\begin{abstract}
The possible role of white blood cells in tissue ischaemia has attracted recent interest. White blood cells can block narrow vessels, particularly if perfusion pressure is reduced or if the cells become activated. To investigate the role of white blood cells in ischaemia microfiltration techniques were used to measure the flow properties of these cells in patients with severe leg ischaemia before and after amputation. Compared with controls white blood cells from patients showed impaired ability to flow through $8 \mu \mathrm{m}$ and $5 \mathrm{um}$ pore filters. This applied to fractionated granulocytes and mononuclear cells as well as to unfractionated mixed white blood cells. White blood cells from blood draining the ischaemic leg had worse filterability than those from arm blood of the same patients. After amputation of the ischaemic leg there was definite improvement, the flow properties of the cells being no longer significantly different from controls.

These abnormalities detected in white blood cells probably reflect activation of the cells by factors released in the ischaemic tissue. As activation alters the mechanical and adhesive properties of white blood cells, a vicious cycle of microcirculatory trapping at low perfusion pressure, activation, tissue damage, and further activation and trapping might contribute to the progressive worsening of tissue ischaemia.
\end{abstract}

\footnotetext{
Department of Haematology, St George's Hospital Medical School, London SW17 ORE

G B NASH, PHD, research fellow

Department of Surgery, St James and St George's Hospitals, London SW12 8HX

P R S THOMAS, FRCS, research registrar

J A DORMANDY, rRCS, consultant surgeon

Correspondence to: Mr Dormandy, St James Hospital.
}

\section{Introduction}

Epidemiological evidence that the white cell count is a good predictor of ischaemic events and recent studies of ischaemia in animal models have led to considerable interest in the possible part played by white cells in the development and progression of tissue ischaemia (see Ernst et al for review'). White blood cells are highly resistant to deformation compared with red cells. In the normal circulation their entry into capillaries may take several seconds and gives rise to intermittent plugging of these vessels. ${ }^{2}$ If the tissue perfusion pressure is reduced numerous white cells may become trapped in the microcirculation. Increased haemodynamic resistance will result which may not necessarily be reversed fully when reperfusion occurs. This type of flow disturbance and capillary blockage mediated by white blood cells has been described in animal models of haemorrhagic shock ${ }^{3}$ and myocardial infarction, ${ }^{4}$ and in perfused isolated organs. ${ }^{5} \mathrm{~A}$ second stage of trapping of white blood cells has been suggested to arise from activation of newly arriving cells by factors released by earlier white cells, possibly as a result of their interaction with endothelial cells. ${ }^{7}$ These activated white cells would be expected to have altered mechanical and adhesive properties, ${ }^{8-10}$ which would increase their tendency to block narrow vessels. Factors released in such circumstances might include leucotrienes, thromboxane, platelet activating factor, and leucocyte derived free radicals. Such factors have been implicated, for example, in changes in neutrophil adhesiveness detected after induction of ischaemia in rat hind limbs."

A cycle of white cell trapping, activation, and endothelial damage and further activation and trapping might theoretically occur in any ischaemic tissue. Previous studies have been carried out using animal models but little clinical data exist on changes in white cells in man. We have therefore evaluated the rheological properties of white blood cells in patients with severe ischaemia of the leg to test the hypothesis that reduced perfusion pressure due to atherosclerosis may initiate a cycle of changes which results in impaired flow of white blood cells. Unfractionated white blood cells and density separated granulocytes and mononuclear cells were tested 
by measuring their rate of flow through microfilters. This method has been shown to be sensitive to changes in mechanical properties resulting from activation of white blood cells. ${ }^{9}$ We compared the white cells from blood drawn from the arm and affected leg of patients and repeated the measurements after amputation of the ischaemic tissue. We thus aimed at detecting any systemic or local effect on the flow properties of the cells and at seeing whether removal of the ischaemia would reverse any abnormalities.

\section{Methods}

\section{SUBJECTS AND BLOOD SAMPLING}

We studied nine patients with occlusive arterial disease requiring amputation (five men, four women; mean age 73 years, range 58-83). Five of small proportion of these cells were fixed in $1 \%$ glutaraldehyde for morphological examination. At the same time $10 \mathrm{ml}$ blood was layered on to two density gradients made up of $2.5 \mathrm{ml}$ Ficoll-Paque (Pharmacia Fine Chemicals, Uppsala) layered above $2.5 \mathrm{ml}$ Mono-Poly resolving medium (Flow Laboratories Ltd, Irvine, Ayrshire). The gradients were centrifuged at $400 \mathrm{~g}$ for 10 minutes and the top layer of platelet rich plasma removed. The gradients were recentrifuged at $800 \mathrm{~g}$ for five minutes and the upper band of mononuclear cells and middle band of granulocytes harvested. Red cells settled to the bottom of the gradient and were discarded. These fractions and the unfractionated white cells were washed twice in phosphate buffered saline (Dulbeco A; Oxoid Ltd, London) plus $5 \%$ plasma and glucose $5.5 \mathrm{mmol} / \mathrm{l}$, resuspended in this medium, and counted. The cell concentration was then adjusted and filtration measurements carried out immediately.

White cell and differential counts were made with a Coulter counter model $S$ plus IV except for the whole blood differentials, which were calculated by using stained blood films. Viability of white blood cells was judged by trypan

TABLE I-Relative flow rates of unfractionated white blood cells, granulocytes, and mononuclear cells after $1 \mathrm{ml}$ of sample had passed through $8 \mu \mathrm{m}$ pore filters. Values are means ( $S E$ in parentheses). (Ten controls, nine patients)

\begin{tabular}{|c|c|c|c|}
\hline & Unfractionated white blood cells & Granulocytes & Mononuclear cells \\
\hline Control arms (A) & $0.46(0.017)$ & $0.55(0.041)$ & $0.305(0.019)$ \\
\hline \multicolumn{4}{|l|}{ Patients: } \\
\hline Preoperative arms (B) & $0.27(0.056)^{\star \star}$ & $0.28(0.055)^{\star \star}$ & $0.063(0.023)^{\star \star}$ \\
\hline Preoperative legs (C) & $0.14(0.031) \dagger$ & $0.26(0.054)$ & $0.045(0.015)$ \\
\hline Postoperative arms (D) & $0.355(0.037)$ & $0.56(0.038) \S$ & $0.220(0.050)$ \\
\hline
\end{tabular}

$\star{ }^{\star} \mathrm{p}<0.01$ for $(\mathrm{B}) v(\mathrm{~A}) . \quad \quad \mathrm{tp}<0.05$ for $(\mathrm{C}) v(\mathrm{~B}) . \quad \quad \mathrm{p}<0.05$ for $(\mathrm{D}) v(\mathrm{~B})$.

TABLE II-Characteristics of samples of white blood cells from 10 controls and nine patients. Values are means (SD in parentheses)

\begin{tabular}{|c|c|c|c|c|}
\hline & \multirow[b]{3}{*}{$\begin{array}{l}\text { Control } \\
\text { arms } \\
\text { (A) }\end{array}$} & \multicolumn{3}{|c|}{ Patients } \\
\hline & & \multicolumn{2}{|c|}{ Preoperative } & \multirow[b]{2}{*}{$\begin{array}{l}\text { Postoperative } \\
\text { arms } \\
\text { (D) }\end{array}$} \\
\hline & & $\underset{(B)}{\operatorname{Arms}}$ & $\begin{array}{l}\text { Legs } \\
\text { (C) }\end{array}$ & \\
\hline \multicolumn{5}{|l|}{ Whole blood: } \\
\hline Total white cell count $\left(\times 10^{9} / 1\right)$ & $7 \cdot 5(1 \cdot 3)$ & $12 \cdot 0(3 \cdot 2)^{\star \star}$ & $12 \cdot 6(3 \cdot 8)$ & $8 \cdot 2(3 \cdot 2) \dagger$ \\
\hline$\%$ Granulocytes & $60.9(6.6)$ & $83 \cdot 5(4 \cdot 5)^{\star \star}$ & $83 \cdot 8(5 \cdot 7)$ & $69 \cdot 7(13 \cdot 1) \dagger$ \\
\hline \% Lymphocytes & $34 \cdot 0(4 \cdot 7)$ & $11 \cdot 2(3 \cdot 9)^{\star \star}$ & $11 \cdot 5(4 \cdot 0)$ & $25 \cdot 5(12 \cdot 1) \mathrm{tt}$ \\
\hline$\%$ Monocytes & $5 \cdot 1(2 \cdot 7)$ & $5 \cdot 3(2 \cdot 3)$ & $4 \cdot 7(3 \cdot 3)$ & $4 \cdot 6(2 \cdot 9)$ \\
\hline \multicolumn{5}{|l|}{ Mononuclear cells: } \\
\hline$\%$ Lymphocytes & $71 \cdot 6(7 \cdot 3)$ & $50.0(15 \cdot 1)^{\star \star}$ & $50 \cdot 1(13 \cdot 2)$ & $64 \cdot 8(12 \cdot 5) \dagger$ \\
\hline$\%$ Monocytes & $21 \cdot 5(5 \cdot 5)$ & $33.7(10 \cdot 2)^{\star}$ & $33 \cdot 1(9 \cdot 0)$ & $26 \cdot 2(7 \cdot 6) \dagger$ \\
\hline Lymphocyte:monocyte ratio & $3 \cdot 6(1 \cdot 1)$ & $1 \cdot 7(1 \cdot 0)^{\star \star}$ & $1.7(0 \cdot 7)$ & $2 \cdot 8(1 \cdot 2) \dagger$ \\
\hline \multirow{2}{*}{$\begin{array}{l}\text { Sedimented unfractionated white cells: } \\
\% \text { "Active" }\end{array}$} & & & & \\
\hline & $12(3)$ & $33(21)^{\star \star}$ & $38(20)$ & $16(6) \dagger$ \\
\hline
\end{tabular}

${ }^{\star} \mathrm{p}<0.05,{ }^{\star \star} \mathrm{p}<0.01$ for $(\mathrm{B}) v(\mathrm{~A})$

$t \mathrm{p}<0.05, \mathrm{ttp}<0.01$ for $(\mathrm{D}) v(\mathrm{~B})$ and $(\mathrm{C})$

Differences between (B) and (C) not significant (paired $t$ tests).

(C) Significantly different from $(A)$ in all variables except percentage of monocytes in whole blood.

the patients had diabetes. All patients had established gangrene with areas of tissue necrosis and were unsuitable for vascular reconstruction. Two patients who had recovered from a previous amputation were re-entered after developing gangrene in the other leg. Samples of venous blood $(20 \mathrm{ml})$ were taken from the arm and affected leg of the patients on the day before amputation. The leg sample was drawn from the long saphenous vein immediately proximal to the area of tissue necrosis, which in most cases affected the forefoot and lower leg. A postoperative sample was taken from the arm after the wound had healed (mean 36 days after amputation). One patient died before the postoperative sample could be taken and a second patient was not available for follow up.

A control group of 10 subjects was matched for age (mean age 67, range 50-92) and sex (five men, five women). Two of the controls were diabetic. Controls provided a single blood sample of $20 \mathrm{ml}$ from the brachial vein. All samples were anticoagulated with dipotassium edetic acid $(1.5 \mathrm{~g} / \mathrm{l})$ and experimental procedures initiated after a standard one hour delay.

\section{PREPARATION OF SAMPLES}

Suspensions of white blood cells were prepared and filterability measured as described. ${ }^{12} 13$ Briefly, unfractionated white cells were separated from $10 \mathrm{ml}$ whole blood by sedimentation under gravity. After sedimentation a blue exclusion and was $>95 \%$ at the finish of the preparative procedures. Fixed unfractionated white blood cells were examined by light microscopy and the proportion with pseudopodia or cytoplasmic irregularities counted. These non-spherical cells were classified as "active."

\section{MEASUREMENTS OF FILTERABILITY}

Filterability was tested by measuring the flow rate of suspensions through Nuclepore filters (Nuclepore Corp, Pleasanton, CA) with nominal pore diameters of 8 or $5 \mu \mathrm{m}$ (actual mean diameters $7 \cdot 2$ and $4 \cdot 6 \mu \mathrm{m}$; manufacturer's data). A St George's Filtrometer (Carri-Med Ltd, Dorking) was used, which measures the flow rate of the suspension as a function of volume filtered at a constant driving pressure. ${ }^{12}$ All flow rates are expressed relative to the flow rate of cell free suspending medium, which was tested for each filter.

When using $8 \mu \mathrm{m}$ filters the pressure was $300 \mathrm{~Pa}$ and the white cell concentration $5 \times 10^{9} / 1$. Three flow parameters were derived, as described ${ }^{12}$ (a) the initial relative flow rate, which characterises the extent of the initial, rapid fall in flow rate; $(b)$ the slow particle resistance, which characterises the subsequent rate of decrease in flow; $(c)$ the relative flow rate after $1 \mathrm{ml}$ of the sample had been filtered. The initial relative flow rate represents the flow resistance of the main population of rapidly flowing cells and the slow 
particle resistance represents a small subpopulation of slowly flowing cells. The relative flow rate after $1 \mathrm{ml}$ of the sample had been filtered represents the contribution from both these types and also from cells which permanently block filter pores. Similar flow measurements were carried out with $5 \mu \mathrm{m}$ pore filters, except that the pressure was $1000 \mathrm{~Pa}$ and the white cell concentration $3 \times 10^{9} / 1$.

\section{STATISTICAL ANALYSIS}

Statistical comparisons were made as follows: $(a)$ preoperative samples from patients versus samples from control arms (Student's $t$ test); $(b)$ preoperative samples from patients' arms versus preoperative samples from affected legs (paired $t$ test); (c) postoperative samples from patients' arms versus preoperative samples from arms (paired $t$ test); (d) postoperative samples from patients versus control samples (Student's $t$ test).

\section{Results}

Table I gives the relative flow rates of unfractionated white blood cells, granulocytes, and mononuclear cells from controls and patients after $1 \mathrm{ml}$ of the sample had passed through an $8 \mu \mathrm{m}$ pore filter. White blood cells from the patients' arms before operation showed significantly impaired flow compared with controls for each of the three white cell preparations $(41 \%$ decrease in flow rate for unfractionated white cells, $49 \%$ decrease for granulocytes, $79 \%$ decrease for mononuclear cells; all differences $\mathrm{p}<0.01$ ). When white cells from the leg and the arm of the same patient were compared preoperatively consistent impairment was found in the flow properties of cells from the leg. Not all differences, however, reached significance in paired $t$ tests. Postoperative measurements on white blood cells from the arms of patients showed improvement for each preparation of cells compared with preoperative measurements $31 \%$ increase in flow rate for unfractionated white blood cells, $100 \%$ increase for granulocytes, $250 \%$ increase for mononuclear cells; all differences $\mathrm{p}<0.05$ ). The postoperative samples from the patients were not significantly different from controls.

The other parameters with $8 \mu \mathrm{m}$ pore filtration (initial relative flow rate, slow particle resistance) showed similar significant differences, as did filtration data obtained with $5 \mu \mathrm{m}$ pore filters (data not shown). In summary, the patterns of abnormalities in flow of white blood cells were: $(a)$ preoperative samples from patients' arms had lower flow rates than control samples; $(b)$ samples from legs flowed slower than samples from arms (though these differences did not always reach significance); (c) postoperative flow was improved and not significantly different from controls.

Table II lists other characteristics of the white blood cells. The white cell count and differential were the same for the preoperative arm and leg samples of whole blood from patients, but patients differed from controls. The patients had a higher white cell count and percentage of granulocytes and a lower percentage of lymphocytes; the percentage of monocytes did not vary significantly among the various samples. Consequently the ratio of monocytes to lymphocytes in the density separated mononuclear fraction was higher for patients before operation compared with controls (table II). Granulocyte fractions from all types of sample contained an average of more than $95 \%$ of these cells (data not shown). In unfractionated samples of white blood cells the percentage of irregularly shaped "active" cells was greater for patients before operation than controls, though no significant difference was found between arm and leg samples. Nor was there any significant correlation between flow properties of white cells and the percentage of active cells on a patient by patient basis in any group. After amputation values for all the above parameters approached those of controls. We emphasise that the filtration tests were carried out at a standard concentration of white cells and so were unaffected by changes in absolute blood counts.

\section{Discussion}

This study shows a pronounced abnormality in the flow resistance of white blood cells in patients with severe leg ischaemia. In normal blood our previous studies have indicated that monocytes are the most resistant white cells followed by granulocytes; lymphocytes flow most rapidly. ${ }^{12}$ In this study purified granulocytes had impaired flow properties in patients with leg ischaemia before operation. This, together with the shift in white cell differential from lymphocytes to granulocytes, would explain the impaired flow of unfractionated white cells. Mononuclear suspensions from patients contained a lower ratio of lymphocytes to monocytes.
Because monocytes are so resistant to filtration their increased proportion might explain the loss of filterability of the patients' mononuclear suspensions.

Based on microscopic observations samples of white blood cells from patients with ischaemia tended to contain more active cellsthat is, cells with psuedopodia or cytoplasmic irregularities. Activation of white blood cells decreases their filterability and is thus a likely cause of the abnormalities in flow detected. These abnormalities were generally greater for blood drawn close to the ischaemic region, and removal of the ischaemic tissue by amputation reversed the abnormal filterability. Changes in the flow characteristics of the white blood cells were therefore directly linked to the presence of ischaemia and may result from factors released in the ischaemic tissue. Activation of white blood cells might arise from activation of complement ${ }^{14}$ or release of thromboxane ${ }^{11}$ in ischaemic tissue or might occur after extended trapping of cells under hypoxic conditions. Activated cells may cause endothelial damage by production of oxygen free radicals and release of lysosomal enzymes, ${ }^{15}$ which in turn may lead to production of leucotrienes and thus further stimulation of white cells. ${ }^{10}$ The inflammatory response to tissue damage will also lead to release of chemoattractants which increase neutrophil adhesiveness. ${ }^{16}$

The rheological changes found in this study would be expected to affect the flow of white blood cells through the microcirculation and support the hypothesis that changes in the flow properties of these cells parallel and indeed contribute to the progress of tissue ischaemia. After some initial insult, such as a decrease in perfusion pressure due to atherosclerosis, a vicious cycle of white cell trapping-activation-endothelial damage and release of activating factors-changes in circulating white cells-further trapping might lead to progressive impairment of oxygen delivery and tissue damage. Such a chain of events has been postulated to occur in experimental myocardial ischaemia in dogs, ${ }^{\gamma}$ and we suggest that a similar process occurs in the muscle of the ischaemic leg in man. Further studies are in progress to test specific markers for activation of white blood cells and to examine whether white cell abnormalities correlate with the clinical severity or progress of the patients.

This research was supported by grants from the British Heart Foundation and Hoechst Pharmaceuticals. We acknowledge the technical work of Mr Barry Christopher and Ms Jayshree Parmar.

\section{References}

1 Ernst E, Hammerschmidt DE, Bagge U, Matrai A, Dormandy J. Leukocytes and the risk of ischemic disease. FAMA 1987;257:2318-24

2 Bagge U, Branemark P-I. White blood cell rheology. An intravital study in man. Advances in Microcirculation 1977;7:1-17.

3 Bagge U. Leukocytes and capillary perfusion in shock. In: Meiselman HJ, Lichtyman MA LaCelle PL, eds. White cell mechanics: hasic science and clinical aspects. New York: Alan R L.iss, 1984:285-94.

4 Engler RL, Schmid-Schonbein GW, Pavelec RS. Leukocyte plugging in myocardial ischemia and reperfusion in the dog. Am f Pathol 1983;111: 98-111.

5 Braide $M$, Amundson B, Chien S, Bagge $\mathrm{U}$. Quantitative studies on the influence of leukocytes on the vascular resistance in a skeletal muscle preparation. Microvasc Res 1984;27:331-52.

6 Braide M, Blixt A, Bagge U. Leukocyte effects on the vascular resistance and glomerular filtration of the isolated rat kidney at normal and low flow states. Circ Shock 1986;20:71-80.

7 Engler RL, Dahlgren MD, Peterson MA, Dobbs A, Schmid-Schonbein GW. Accumulation of polymorphonuclear leukocytes during three hours' experimental myocardial ischemia. $A m$ f
pol polymorphonuclear leukoc
Physiol 1986;251:H93-100

8 Schmid-Schonbein GW, Skalak R, Sung KLP, Chien S. Human leukocytes in the active state. In: Bagge U, Born GV, Gaehtgens P, eds. White blood cells, morphology and rheology as related to function. The Hague: Martinus Nijhoff, 1982:21-31.

9 Nash GB, Jones JG, Mikita J, Christopher B, Dormandy JA. Effects of preparative procedures and of cell activation on flow of white cells through Micropore filters. Br $\mathcal{Y}$ Haematol (in press).

10 Harlan JM. Leukocyte-endothelial interactions. Blood 1985;65:513-25

11 Anner H, Kaufman RP, Kobzik L, Valeri CR, Shepro D, Hechtman HB. Pulmonary leukosequestration induced by hind limb ischemia. Ann Surg 1987;206:162-7.

12 Nash GB, Jones JG, Mikita J, Dormandy JA. Methods and theory for analysis of flow of white cell subpopulations through Micropore filters. Br I Haematol (in press).

13 Mikita J, Nash GB, Dormandy JA. A simple method of preparing white blood cells for filterability testing. Clinical Haemorheologv 1986;6:635-9.

testing. Clmical Haemorheolog $1986 ; 6: 635-9$.
14 Bengston A, Holmberg P, Heidman M. The ischemic leg as a source of complement activation. Brf S Surg 1987;74:697.700.
.

15 Lucchesi BR, Mullane KM. Leukocytes and ischemia-induced myocardial injury. Annu Rer Pharmacol Toxicol 1986;26:201-24

16 Williams TJ, Jose PJ, Forrest MJ, Wedmore CV, Chugh GF. Interactions between neutrophils and microvascular cells leading to cell emigration and plasma protein leakage. In: Meiselman HJ, Lichtman MA, LaCelle PL, eds. White cell mechanics: basic science and clinical aspects. New York: Alan R Liss, 1984: 195-208.

(Accepted 12 Apral 1988) 